\title{
PERSISTÊNCIA DO COLONIALISMO: PRIMAVERA ÁRABE COMPREENDIDA ALÉM DE SEU TEMPO
}

Henrique Muzzio henrique.muzzio@ufpe.br

Professor do Programa de Pós-Graduação em Administração, Universidade Federal de Pernambuco - Recife - PE, Brasil

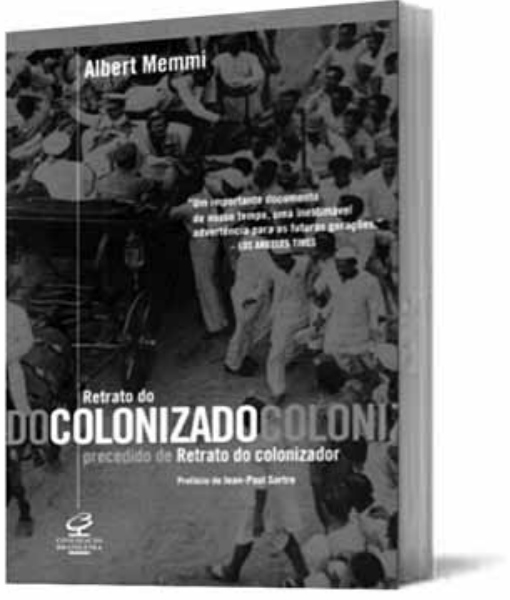

\section{RETRATO DO COLONIZADO PRECEDIDO DE RETRATO DO COLONIZADOR}

Albert Memmi. Rio de Janeiro: Civilização Brasileira, 2007. 190 p.

A primavera árabe causou rupturas importantes no contexto sociopolítico de países que viviam há décadas sob ditaduras, nos possibilitando um amplo aspecto de análise acadêmica. Se esse movimento ganhou força atualmente, ele não é recente. As nações africanas e árabes envolvidas nos conflitos espelham as condições inadequadas de um contingente de países que viveu, por muito tempo, como colonizado e, por vezes, ainda não se libertou dessa sombra, seja pela dependência econômica, seja pela condição de vítima de opressores locais, normalmente subsidiados por nações ricas interessadas, não mais na trabalhosa exploração física, mas, sim, na exploração comercial, mais rentável na pós-modernidade.

O que faz de uma obra um clássico? Entre as razões, estão o reconhecimento de sua importância pelos pares e a sua capacidade de explicação de um fenômeno continuar válida ao longo do tempo. Essas condições estão presentes na obra de Albert Memmi, escrita na década de 1950, cuja leitura pode ser feita em conjunto com outro livro seu, mais recente: Retrato do Descolonizado Árabe Mulcumano e de Alguns Outros (Rio de Janeiro: Civilização Brasileira, 2007). Um exemplo do reconhecimento foi o agraciamento com o Grande Prêmio da Francofonia, em 2004. Da condição de sua explicação atual, a primavera árabe evidencia que a colonização ainda não está superada, e a leitura dessa obra configura-se de grande importância para a compreensão desse fenômeno.

Na primeira parte do livro, prefaciado por Jean-Paul Sartre, Memmi expõe o retrato do colonizador, que toma duas possíveis faces: aquele colonizador que recusa a si mesmo pela defesa do colonizado, mas nem por isso elimina a sua condição, e aquele colonizador que aceita a si mesmo e não apresenta as contradições do primeiro, sendo um ser naturalmente defensor da condição colonialista e de todos os males de miséria e de ignorância que ela produz.

$\mathrm{Na}$ segunda parte, o autor aborda o retrato do colonizado. Primeiramente, a sua condição é retratada de modo uniforme, ou seja, coletiva e de conotação negativa, utilizando-se da ideologia para a construção e o reforço dessa imagem. Segundo Memmi, "toda ideologia de combate compreende, 
como parte integrante de si mesma, uma concepção do adversário. Ao aceitar essa ideologia, as classes dominadas confirmam, de certa maneira, o papel que lhes foi atribuído. Isso explica, entre outras coisas, a relativa estabilidade das sociedades; a opressão é, de boa ou má vontade, tolerada pelos próprios oprimidos".

Em seguida, o autor explora a situação do colonizado em relação a seus valores, ao seu histórico, à amnésia cultural, a sua condição de carência etc. Para ele, "a sociedade colonizada é uma sociedade enferma em que a dinâmica interna não consegue mais produzir estruturas novas. Seu rosto endurecido pela história não passa de uma máscara, sob a qual ela sufoca e agoniza lentamente. Uma sociedade como essa não pode assimilar os conflitos de gerações, pois não se deixa transformar".

Por fim, Memmi expõe duas respostas possíveis desse colonizado: cultivar o amor pelo colonizador e o ódio de si, que o autor acha inapropriado, e aquela que é sua defesa, a revolta. De acordo com ele, "para o colonizado, não há outra saída a não ser a consecução do fim da colonização. E a recusa do colonizado só pode ser absoluta, isto é, não apenas revolta, mas superação da revolta, ou seja, revolução".

O ponto central da obra é a negação da opressão colonizadora, que deve partir de uma consciência do colonizado de sua condição degradante para que este possa ter sua libertação completa, ou para a reconquista de si mesmo, fugindo de uma condição que desmoraliza, não só materialmente, mas espiritualmente também. Para tal, o colonizado deve não apenas se revoltar, mas, sim, fazer uma revolução.

Não é difícil fazer um paralelo com a primavera árabe, que não é fruto de um colonialismo clássico, aquele em que as nações desenvolvidas possuíam o domínio territorial, mas, sim, do neocolonialismo, que se caracteriza, entre outros fatores, pela independência territorial e política, mas ainda prevalecendo condições comerciais desiguais e preconceitos contra a cultura local e os costumes tradicionais. O que essa revolta atual tem de novo, além de sua propagação apoiada no uso das redes sociais, é que não se luta mais por independência, mas, sim, por avanços sociais, democracia, liberdade de expressão, eleições livres etc. Nesse sentido, a obra de Memmi continua incrivelmente atual, ajudando a explicar a primavera árabe muito além de seu tempo.

Diante da contemporaneidade dos fatos, ainda há uma carência de obras em português, mas o livro de Memmi contempla de maneira satisfatória as origens das revoltas. O colonialismo analisado sob a ótica ocidental é abundante. Nesse caso, um ponto a mais de interesse dessa obra são a origem e o histórico do autor. Filósofo e sociólogo, Memmi nasceu na Tunísia, em 1920, ainda sob o domínio francês, e viveu as contradições de ter origem judaica em um mundo mulçumano. Após a independência, também não encontrou espaço na Tunísia liberta, optando por viver na própria França, onde lecionou no Centro Nacional de Pesquisa e na Universidade de Paris (Sorbonne).

As tensões históricas no Oriente Médio, e que continuam na ordem do dia, são exemplos de uma sociedade global colonizadora, caracterizada por uma visão de mundo ocidental, machista e capitalista, que vende a imagem de que só uma realidade é possível, e, o que é pior, muitos compram essa imagem sem a capacidade de analisar criticamente os seus objetivos.
Os desafios agora são maiores para as nações não desenvolvidas. Disfarçada em relações desiguais que a sociedade do conhecimento torna possível, a neocolonização exige um grau mais inteligente para livrar as sociedades oprimidas dessa relação conflituosa. As revoltas são hoje contra ideias opressoras e desvalorização cultural. O inimigo a ser combatido está dissipado em produtos e serviços, e utiliza-se dos meios de comunicação para prevalecer com seus ideais de exploração cultural, e, em muitos casos, com o apoio financeiro e bélico aos ditadores locais. Paradoxalmente, a queda dos ditadores depostos ocorreu com o apoio das mesmas nações ocidentais que antes lhes asseguravam o poder, certamente, prontas para manter seus domínios junto os que vierem em substituição.

Para os acadêmicos da área de gestão, essa obra pode ajudar a compreender o quão é profundo entender as relações entre países não desenvolvidos e desenvolvidos e o quanto é necessário superar um pensamento colonial, que normalmente está presente nas sociedades das ex-colônias, inclusive na própria academia.

Por fim, exemplos de ações para acadêmicos e profissionais de gestão inspirados nesse livro: a sensatez no uso de soluções locais para os problemas gerenciais locais e a necessidade de compreensão de como pensa o consumidor brasileiro, bem como a pertinência em desenvolver modelos de gestão adaptados à cultura local, inclusive no plano subnacional, pois o Brasil é culturalmente distinto entre as suas regiões. Enfim, essas ações merecem um maior esforço coletivo local, para que as propostas possam significar uma verdadeira transformação social, o que, certamente, não será alcançado, se pensarmos como colonizados. 